\title{
FUSTIGATION IMPOLITENESS, EMOTIONS AND EXTIMACY IN ARGENTINE MEDIA CELEBRITIES
}

\author{
Silvia Kaul de Marlangeon \\ Universidad Nacional de Río Cuarto \\ X5804BYA Río Cuarto, Córdoba, Argentina
}

\begin{abstract}
The aim of this paper is to examine the connection among fustigation impoliteness - a type of impoliteness within Kaul de Marlangeon's $(2005,2008)$ and Kaul de Marlangeon \& Alba-Juez (2012) taxonomy of impolite acts, emotions and extimacy, focusing on Argentine media celebrities of the Río de la Plata cultural context. This article highlights the phenomenon of speaker's or hearer's extimacy as a volitional form within an aggressive relationship, used for the promotion of the speaker's ego through media exhibitionism that enlarges one's own and others' intimacy and sharing with the public. Within a pragmatic sociocultural approach, this work intends, on the one hand, to investigate fustigation impoliteness as a usual practice of violent public interactions of media celebrities, and on the other hand to consider when such expressions are due to the extimacy of the speaker or to that attributed to or imposed on the hearer or on a third party by the speaker.
\end{abstract}

Keywords: fustigation impoliteness, emotions, speaker's extimacy, extimacy imposed on the hearer

\section{INTRODUCTION}

According to Lipovetsky (2002), at a global level, it can be argued that there is a shock of cultural traditions on the individual and society as a whole, in an era of mass consumption.

Postmodern society is characterized by a hedonistic individualism whose principal feature is an exacerbated narcissism.

This is a process of personalizing as a global strategy, that is to say, the individual searches and manages his or her identity and particular characteristics and interests. This attrition of social identities and the rapid destabilization of personalities pull people from conventional and traditional forms of social order. New social legitimacies of hedonist desires provide a distinctive meaning to the free development on individual's intimate personality.

Individuals feel the need to express publicly their intimate experiences. Whatever the nature of the message emitted, the act of communicating is imposed over of the content transmitted for the main purpose of enhancing the individual's public and social face.

With the fast-paced globalization of consumers found today (Bauman, 2007), broader areas of human conduct have been relieved from current social regulations. In this deregulated and privatized setting, individuals establish the limits of their individual responsibility and assume the responsibility for choices and their consequences. Bauman remembers Bourdieu who pointed out that in the latter part of the twentieth century, 
obligatory patterns of behaviors had been replaced by stimulation and seduction, and the arousal of new needs and desires.

Additionally, virtual communication makes interaction more superficial, more intense and often aggressive. Such mass aggressive behaviors reveal the desire of individuals to convey their own intimate experience, without any particular constraints and without the use of coercive controls over freedom of expression.

Furthermore, trivialization of swearing occurs with the consequent loss of the infringing intensity and the mitigation of the offenses that they previously presented. New codes of conduct are followed among social actors, different from those of modernity, during which private life was perceived as a safe space for the free and full development of one's personality and individual freedom. These new codes of behavior are frequently exhibited by a direct verbal violence through fustigation impoliteness a type of impoliteness within Kaul de Marlangeon's (2005-2008) and Kaul de Marlangeon \& Alba-Juez (2012a) taxonomy of impolite acts.

Social tolerance towards these new modes of communication is increasing, but, simultaneously and contradictorily, a lack of trust among individuals is promoted as well. This mistrust that becomes mutual prevention, that is to say, a mutually defensive suspicious attitude, is another ingredient of the impolite behavior (Kaul de Marlangeon, 2010).

The aim of this paper is to examine the connection among fustigation impoliteness, emotions and extimacy, focusing on Argentine media celebrities of the Río de la Plata context of culture. This article highlights the phenomenon of speaker's or hearer's extimacy as a volitional form inside of an aggressive relationship, used for the speaker's ego promotion through media exhibitionism that enlarges one's own and other's intimacy and sharing with the public.

In connection with the aim of this paper, on the one hand, it is important to analyze fustigation impoliteness, as habitual practice in violent public demonstrations of media celebrities and their impacts on commentators social networking in the cyber-society of the Río de la Plata cultural context. On the other hand, it has been considered necessary to analyze how such public demonstrations emerging from public and private conflicts and exhibiting negative emotions are due to the extimacy of the speaker or to that attributed or imposed by the speaker on the hearer.

This work necessarily adopts a pragmatic-socio-cultural framework (Bravo, 2009) to describe the situated use of communicative linguistic resources within their specific socio-cultural context, because this approach considers the socio-cultural variability of the communicative situation and enables the analyst to identify the shared knowledge within the speaking community itself. Furthermore, the emotions involved in the impolite acts are also associated with their respective socio-cultural and situational contexts.

The following sections 2, 3, 4 and 5 present the theoretical framework: a summary of fustigation impoliteness; the significant correlation between negative emotions and fustigation impoliteness; the extimacy of the speaker and, above all, the issue of the extimacy attributed to or imposed on the hearer or on a third party by the speaker. The remaining Sections contain the corpus and methodology, the textual materials, the analysis and conclusions. 


\section{FUSTIGATION IMPOLITENESS}

From a socio-cultural point of view, I described what I call fustigation impoliteness, metaphorically speaking as whipping somebody (Kaul de Marlangeon, 2005-2008 and Kaul de Marlangeon \& Alba-Juez, 2012a). This kind of impoliteness is shown as verbal aggression from speaker to hearer, consisting of voluntary and strategic behavior intended to damage the hearer's face with the purpose of confronting a challenging situation, or of becoming involved with it. These acts of fustigation impoliteness tend to secure confrontation in discourse because they are intended for offending, lambasting, belittling, humiliating, exasperating, denigrating or even, cancelling the hearer. For this reason they tend to be on record.

Fustigation impoliteness as a type of impoliteness act recognizes two essential motivations: refractoriness and exacerbated affiliation.

Each one of these motivations can be seen from two perspectives: one defensive and the other, offensive.

- If the impolite speaker is a follower of the group, he attacks the hearer when he perceives in the hearer attitudes ranging from great autonomy with respect to the group to opposition to it. There is simultaneously, on the part of the speaker, defense of the values of the group and rejection of those that oppose the group.

- If the impolite speaker is refractory to the group, he attacks the hearer when he perceives in the hearer affiliation to the group. There is simultaneously, on the part of the speaker, a primary attack to the values of the group and an implicit defense of the values of his own group.

Refractoriness is defined as the exacerbated autonomy of considering oneself and being considered by the others as an opponent to the group; whereas, exacerbated affiliation involves seeing oneself and being seen by others as a part of the group, with the right to choose impoliteness in its defense.

Table 1 summarizes the definition of fustigation impoliteness.

Table 1

Epitome of refractoriness and exacerbated affiliation, the two categories of fustigation impoliteness

\begin{tabular}{|l|l|}
\hline \multicolumn{2}{|c|}{ Fustigation Impoliteness (determined by individual and variable socio-cultural factors) } \\
\hline refractoriness & $\begin{array}{l}\text { The individual perceives himself and is perceived } \\
\text { by others as an opponent of the group. }\end{array}$ \\
\hline exacerbated affiliation & $\begin{array}{l}\text { The individual perceives himself and is perceived } \\
\text { by others as a follower of the group. }\end{array}$ \\
\hline
\end{tabular}

\section{EMOTIONS}

From the very beginning, politeness study as well as impoliteness study were included in the emotional communication domain (Brown y Levinson, [1978]1987; Arndt y Janney, 1985; Kaul de Marlangeon, 1995, inter alia); it is natural that emotions have been closely associated to matters of (im)politeness behaviors. In the field of impoliteness, a number of negative emotions are directly interlinked as productive factors in introducing aggressiveness in social relations. 
Negative emotions are characterized by producing an unpleasant experience. These individual patterns of expressive behavior are basically anger, fear, disgust and sadness (Piqueras et al. 2010). Negative emotions also include social emotions that acquire meaning in relation to other individuals, such as jealousy and envy (Chóliz y Gómez, 2002).

Fustigation impoliteness as a phenomenon experiences the greatest degree of emotional intensity. According to Andries (2011:30), emotion intensity refers to the force with which an emotional state is experienced.

In fustigation impoliteness there is a correlation between the high intensity of the degree of injury that the hearer receives and the higher emotional intensity of the speaker shown by certain indicators such as intonation and negative emotional expressions (Kaul de Marlangeon, 2017). Other non-verbal signs (facial expressions and body language) are beyond the scope of this paper. With regard to the hearer, his emotional expression will depend on his subjective evaluation of the speaker's act, on his self-control, and his individual emotional sensitivity.

Fustigation impoliteness can be presented as anger or rage on the part of the speaker, and for this reason, it channels emotions as discursive constructions according to a particular sociocultural context.

\section{SPEAKER'S EXTIMACY}

Extimacy is a term coined by Lacan and collected by Tisseron with its own specific meaning.

Tisseron (2011) claims that intimacy is essential to human life, but it is incessantly affected by the wish for extimacy or the process that repositions some elements of intimate human lives into the public domain so as to have a feedback of their value. In extimacy, private actions and behaviors are taken out of the protected space of intimacy and exposed openly to the audience quite naturally in a new type of society, called "confessional" by Bauman.

Ehrenberg (quoted by Bauman, 2012: 254), an analyst of the complex history of the modern individual, tried to locate the birth date of the late-modern cultural revolution that guided us in the liquid-modern world in which we live. Ehrenberg chose an autumnal Wednesday evening in the 1980's, on which Vivienne, an ordinary French woman, declared during a TV talk show that she had never experienced an orgasm during her marital life because her husband was afflicted with premature ejaculation.

Bauman makes clear what was revolutionary in Vivienne's declaration to justify Ehrenberg's choice: private acts being revealed and talked about in public and the use of the public arena to vent about a matter of scrupulously private significance. These two connected aspects legitimized the public use of the language developed for private conversations. According to Bauman, this is the beginning of the modern confessional society.

Tisseron (2011) argues that intimacy contributes at the same time to the development of self-esteem, to the establishment of a richer intimacy, and to the creation of additional social ties, but it differs from both exhibitionism and conformism. For his part, Bauman claims that the advent of the confessional society signals the pyrrhic triumph of privacy and its fall. Privacy has invaded and colonized the public realm, but at the expense of losing its right to confidentiality. 
In this paper, I address the extimacy of the speaker understood as the process by which an individual exposes fragments of his / her inner being to others (interlocutor and network commentators), in order to be validated by them.

I would like to make clear that in this paper I only deal with the issue of the extimacy of the speaker to promote his/her ego or self-praise as a global personalization strategy looking for a hedonistic individualism and for a need of self-image. Conversely for Tisseron, extimacy of the speaker, the concept here developed, should not be understood as a capacity for empathy, it is a need for exhibitionism; this need emerges because of the nature of the antagonistic tenor of relationships in which the protagonists are engaged.

\section{EXTIMACY ATTRIBUTED TO OR IMPOSED ON THE HEARER OR ON A THIRD PARTY BY THE SPEAKER}

In my definition, extimacy attributed to or imposed on the hearer or on a third party by the speaker, is a phenomenon understood as a process by which the speaker reveals to others, that is to say, the large audience of the general public, or the audience of the cyber public, fragments of his/ her interlocutor's personal life or fragments of a third party's personal life that the speaker attributes to the interlocutor or to a third party or imposes on them for the purpose of causing damage and discrediting them. In this way the speaker confronts the interlocutor facing an unwanted exposure in the area of private or family life and the reduction of his/ her personal public self image or personality.

A detailed review of the data allows me to apply this concept to impoliteness theory within fustigation impoliteness through refractoriness or exacerbated affiliation, as shown in the following Table 2 .

Table 2

Ways in which extimacy can be attributed or imposed

\begin{tabular}{|l|l|l|l|}
\hline \multicolumn{4}{|c|}{ Extimacy attributed to or imposed on the hearer or a third party by the speaker } \\
\hline $\begin{array}{l}\text { attributed } \\
\text { to an interlocutor }\end{array}$ & $\begin{array}{l}\text { when the speaker treats } \\
\text { publicly and without offering } \\
\text { any proof, private matters } \\
\text { regarding his / her interloc- } \\
\text { utor, and as a conse- } \\
\text { quence, the speaker hurts } \\
\text { the interlocutor and falls } \\
\text { this one into disrepute }\end{array}$ & $\begin{array}{l}\text { imposed } \\
\text { on an interlocutor }\end{array}$ & $\begin{array}{l}\text { when the speaker reveals to the } \\
\text { public personal information } \\
\text { concerning his / her interlocutor, } \\
\text { who perceives that fact, on one } \\
\text { hand, as an unwanted intrusion } \\
\text { into his / her private life, and on } \\
\text { the other, as a will of the speaker } \\
\text { of hurting him/ her and of falling } \\
\text { them into disrepute }\end{array}$ \\
\hline $\begin{array}{l}\text { attributed } \\
\text { to a third party }\end{array}$ & $\begin{array}{l}\text { when the speaker treats } \\
\text { publicly and without offering } \\
\text { any proof, private matters } \\
\text { regarding the third party } \\
\text { involved, and as a conse- } \\
\text { quence, the speaker hurts } \\
\text { and falls that third party into } \\
\text { disrepute }\end{array}$ & $\begin{array}{l}\text { imposed } \\
\text { on a third party }\end{array}$ & $\begin{array}{l}\text { when the speaker reveals to the } \\
\text { public personal information } \\
\text { concerning the third party in- } \\
\text { volved, and this one perceives } \\
\text { that fact, on one hand, as an } \\
\text { unwanted intrusion into his / her } \\
\text { private life, and on the other, as } \\
\text { a will of the speaker of hurting } \\
\text { him/ her and of falling him/ her } \\
\text { into disrepute }\end{array}$ \\
\hline
\end{tabular}




\section{CORPUS AND METHODOLOGY}

The textual materials selected for this monolingual study were collected within a diatopic variety (Coseriu, 1981) of Spanish language, the Río de la Plata variety, spoken in Argentina, and within the same particular sociocultural group, Argentine media celebrities.

The corpus has been picked up verbatim from intense public interactions of media celebrities and from the subsequent public comments of social networking sites, from 2014 until now. These data are used for the purpose of addressing the relationship between impoliteness and the emotions present in these comments.

The methodological frame of sociocultural pragmatics enables the study to proceed inductively, and can be used to examine social interactions through the use of language as intentional behavior. I analyze and describe human conduct developed linguistically into the texts, as a product of discursive activity; it is known that the text is inseparable from the total context of situation and culture, especially the nature of the relationships involved.

I assume an emic description which enables considering individual behaviors not as external events, but as their personal perspective of social actors.

From a methodological point of view, the assessments of network commentators provide the necessary data for the apprehension of the speaker's spontaneous reality in their social context and the apprehension of cultural premises (Bravo, 1999), that is to say, the shared and consensual information about interpersonal relationships available in the communicative situation. Such data guide the analyst in a spontaneous consultation process (Kaul de Marlangeon, 2012b) that confirms or rectifies the introspective analysis (Fraser, 1994; Bravo, 2009) previously done.

\section{TEXTUAL MATERIALS}

(1) El 21 de octubre de 2016, Moria Casán, actriz y ex vedette de 70 años y su hija, Sofía Gala, actriz, de 29 años, asisten al programa televisivo Intrusos para ser entrevistadas.

En el curso del programa Moria espeta a Sofía:

— “Te gustan las minas, me dijiste: ‘¿dónde están las brasileñas que me las quiero agarrar?'. Estás re homo flair, nena, ¡besándote en la boca con tus chicas!” Moria enfatiza: "Ésta se besa en la boca con las amigas delante del marido".

Frente a la incomodidad de la situación, ruborizada y entre risas, responde Sofía:

— “ ¡No tengo nada para decir!” y aclara: "Siempre me han gustado mujeres, pero jamás me enamoré de una. Me gusta besar a las mujeres".

Luego de lo cual las dos mujeres entablan una tensa discusión.

Fuente: Teleshow

On 21 October 2016, Moria Casan, an 70-year old, actress and former showgirl, and her daughter, Sofia Gala, 29-year old actress, attend the television program Intrusos to be interviewed.

During the live program Moria asked Sofia:

- "You like women, you told me. Where are the Brazilian women because I want to trap them."

"You are very Lesbian, babe, kissing your girls on the mouth." Moria emphasizes:

"She kisses on the mouth with her girlfriends in front of her husband." 
Faced with the uncomfortable situation and flushed look of the face with laughter, Sofia replies:

- "I have nothing to say" and she clarifies: "I have always liked women, but never I fell in love with someone. I like to kiss women."

Then the two women start a tense discussion.

Source: Teleshow.

Some network comments:

que duo estas jaja quiero ser amiga de sofia así nos enfiestamos todas

what a pair (laugher) I want to be Sofia's friend, so can all have fun

la vieja reputa, falopera, ladrona

the old whore addict shoplifter

PARA SER TAN REPUTAS Y RELAJADAS NO TUBIERON QUE ESTUDIAR LAS COGIERON TANTOS MILES DE MACHOS QUE YA PUDEN HABLAR DE PUTA A PUTA* SIN ACORDARSE QUE SON MADRE E HIJA*

To be so whored and relaxed that they didn't have to study, they fucked so many thousands of guys that they presently can now speak whore to whore without remembering that they are mother and daughter

(2) En una sucesión de confesiones mediáticas a corazón abierto, Fabián Cubero, futbolista, confirmó su separación de Nicole Neumann, modelo. El futbolista habló de la difícil situación que atraviesa y cómo está lidiando con la crisis para resguardar a las tres hijas.

Con la modelo de viaje por Europa (y envuelta en un escandaloso rumor sobre un tercero en discordia instalado en Italia), Cubero reveló que hace tiempo que no tiene sexo con Nicole.

"Yo le decía, tengo ganas de acariciarte, de darte un beso... y eso me fue desgastando", confesó en el programa televisivo Los Ángeles de la Mañana. "Tema de intimidad, hace rato que no tenemos porque ella tiene la cabeza en otra cosa. Yo quería y ella no", aseveró.

Fuente: Rating Cero.com 09/05/2017

In a series of media openhearted confessions, Fabian Cubero, professional footballer, confirmed his separation from Nicole Neumann, fashion model. The footballer spoke on the current difficult situation and how he is dealing with the crisis to protect his three daughters.

With his ex-wife travelling through Europe and involved in a scandalous rumor of another man that lives in Italy, Cubero revealed that for some time he had not had sex with Nicole.

"I told her, I want to caress you and give you a kiss... and that deteriorates the relation" he confessed in the television programme "Los ángeles de la mañana". "It has been a while since we have been intimate because she has other things in mind. I wanted to have sex and she did not", he said.

Source: Rating Cero.com 09/05/2017

Some network comments:

Y PENSAR QUE ESTA RUBIA LA NINGUNEABA A PAMPITA!!! MIRANDO LA PAJA EN EL OJO AJENO Y HACIENDO CASO OMISO A LA VIGA EN SU OJO. CUBERO SOS DIVINO...TODO PASA Y ESTO PASARA TAMBIENJ 
And to think that this blond underestimated Pampita!!! (another fashion model with matrimonial problems). It's the pot calling the kettle black! Cubero, you are divine... anything goes and this too will pass!

Que sincero, toda la suerte, en poco tiempo etapa superada sos un grande como persona, NO TE MERECE

How sincere he is, all the best!, in a short period of time, this stage will be overcome; you are a great person, she does not deserve you.

Nunca me gusto esta tipilla fria! y el tampoco un cornu.. todo vuelve I have never liked this cold girl nor him, a cuckold ...it all starts again

Pobre Cubero, re cornudo! Alta yegua resultó ser@nikitaneumann Poor Cubero, super cuckold. She proved to be a great mare.

(3) El ex candidato presidencial, Daniel Scioli, dijo esta noche en televisión que Gisela Berger "está embarazada" y que será "papá a los 60 años". Pero un rato después la propia modelo, completamente indignada, afirmó que el ex gobernador le había pedido que se hiciera "un aborto".

"Ahora quiere formar la familia perfecta ... pero quería que me haga un aborto. A-BORTO”, afirmó Gisela Berger y agregó: "Cuando me entero de que estoy embarazada y se lo digo, su reacción fue, 'No. Esto es una cagada, esto es una cagada. ¿No hay algo para hacer?"”.

"No puedo creer esto. Desde que pasó lo que pasó con Sofía Clérici, él no me llamó más. Apenas me pidió perdón y obviamente trató de componer la situación y no tirar todo lo que habíamos construido hasta el momento", afirmó la modelo.

Aseguró que Scioli dijo específicamente la palabra "aborto": "En tres meses hablando del tema se nombró todos los sinónimos que te puedas imaginar, incluida esa. El primero es, '¿y no hay algo para tomar para hacer que esto baje? Así arranca”.

Fuente: Clarín espectáculos 10/05/17

The former governor and a presidential candidate, Daniel Scioli, said on television tonight that "she, (Gisela Berger, his girlfriend, a fashion model of 27 years of age) was pregnant" and "he will be a father at age 60". But, mintues later, showing her indignation, the fashion model said that the former governor had asked her "to have an abortion".

"Now he wants to start a perfect family... but before he wanted me to have an abortion. A-BOR-TION", alleged Gisela Berger. She adds: "when I found out that I was pregnant I told him, but his reaction was 'No, this is shit, this is shit, is there something to do? ",

"I don't believe this. After everything that happened with Sofia Clérici (a recent lover of the former governor), he doesn't call me. He barely apologized. Obviously, he tried to repair the situation and not undermine all we had built together up until now", the model said.

She reaffirmed Scioli specifically said the word "abortion": "This has been a topic of discussion for three months and he searched for all the synonyms that one can imagine, including that. The first was 'Isn't there something to drink to end this? And so on".

Source: Clarín espectáculos 10/05/17 
Some network comments:

Sinverguenzas cinicos y muy mentirosos. Mientras esta srta viajaba con plata del pueblo no se quejaba. Estar al lado de ese sujeto ya dice mucho de ella. Yo no apoyo el aborto. Conmen, cynics and liars. While this young lady traveled with the people's money, she did not complain. To be on that man's side, it says a lot about her. I don't support the abortion.

ESTE ES MALTRATADOR, SE PUEDE VER EN KARINA CUANDO HACÍA UNA NOTA, SIEMPRE MUY MESURADA AL RESPONDER, CON MIEDO.

This is a violent abuser, this can be clearly seen in Karina (his ex-wife) when she replied to a request, she replied in a measured way, with fear.

UN COBARDE!!! DEBERIA DENUNCIARLO ESTA CHICA POR PEDIRLE ABORTAR, ES UN DELITO!!!

He is a coward!!! That girl should denounce him for asking her to abort.

Esta basura de persona estuvo cerca de ser presidente, con que satisfacción puedo decir que jamas le puse un solo voto.

This person is trash and he came close to being the President; how it pleased me to say that I have never voted for him.

(4) Barby Franco (26), modelo y bailarina en un espectáculo teatral, reveló el motivo de la separación de Fernando Burlando (52), abogado mediático, con quien estuvo en pareja durante cinco años. La modelo contó que parte de la crisis fue porque el abogado quería mantener relaciones sexuales todos los días.

"En cinco años de relación, lo normal para nosotros era cinco veces a la semana. ¡Un montón!?", explicó Barby este lunes en Intrusos. "En el verano estaba muy cansada, me dolía todo el cuerpo, a veces teníamos tres funciones. Él quería seguir ese ritmo y hacerlo todos los días, lo hacíamos tres veces por semana, y a veces discutíamos por eso".

Fuente: Ratingcero.com 19/06/16

Barby Franco, (26) a fashion model and a dancer in a theatre show, revealed the reasons for the separation from her partner, Fernando Burlando (52), a media lawyer, with whom she was in union for five years. The fashion model said that much of the crisis was because the lawyer wanted to have sexual relations every day.

"For five years of relations, it was normal for us five times a week. A lot!!! She explained this Monday in Intrusos (a televison programme). In the summer I was really tired, my whole body afflicted me, every so often we (the cast of dancers) had three functions. But he wanted to keep that pace and to do so every day. We had sexual activities three times a week, and sometimes we fight about it".

Source: Ratingcero.com 19/06/16

Some network comments:

Me pregunto si volverá a la villa 31 de donde vino?

I wonder whether she will return to "Villa 31 " (a slum), the place where she came from.

Se le acabo el lujo a buscar otro porque trabajo no.

Luxury run out, she should look for a new one, because she does not want to work.

Que lastima me gustaba la pareja

What a pity! I liked this couple... 
(5) Fragmento de la pelea radial entre Beto Casella y Luis Ventura:

C: Vas a terminar en cana. No podés caminar por la calle. Sos un alcahuete.

V: Te voy a volar esa peluca. Vos no me hacés ni cosquillas.

C: Me cago en vos Ventura. Vení a tirarme del pelo. ¿Qué tiene que ver la peluca? ¿Tan pobre de argumentos sos? A mí me chupás un huevo.

V: Guarda, a ver si te salta el stent...

C: Vos sos una porquería. Alguien te tiene que poner freno. Vos apretás a todo el mundo. Hacele un favor al periodismo, retirate!

Fuente: Ciudad.com 05/05/14

Fragment of radio fight between Beto Casella and Luis Ventura (both well known television and radio journalists):

C: You will go to jail. You cannot even walk the street. You are a gossip.

$V$ : I will remove your wig. Don't make me laugh.

C: Screw you, Ventura. Come pull my hair. What does a wig have to do with it? Is your argument really so weak. Suck an egg.

$V$ : Be careful! Check your stent...

C: You are a mess. Someone need to stop you. You press everybody's buttons.

Please, do favor journalism a favor: Step down!

Source: Ciudad.com 05/05/14

Luis Antonio Ventura@LuisVenturaSoy

AHH, ME OLVIDABA.... A VOS TAMBIEN PELADO CASELLA... VOS HACES HUMOR CONLOS DEMAS? HOY EMPIEZAN LOS CHISTES DE TU PELUCA...

Oh, I forgot to say ... you too, bald Casella... you joke with the others, today begin the jokes about your wig...

Retweets:

@,LuisVenturaSoy hace falta tanta mierda?? Te hace feliz todo eso??? grasadas al por mayor Is this shit necessary? Does it make you happy? Such vulgarity

$@$ @LuisVenturaSoy vos hablas de todo el mundo...cuando alguien habla de vos, es una basura? You criticise everyone... when someone speaks about you, is he trash?

\section{ANALYSIS}

The texts display a common denominator: they address private matters of media celebrities.

All of the texts show the free development of their personality. In other words, the extimacy of the protagonists and the extimacy attributed to or imposed on the hearer or on a third party by the speaker. Those texts present the following cases: Text (1) and (5), extimacy imposed on the hearer by the speaker; Text (2), Text (3) and Text (4), speaker's extimacy and extimacy attributed to the third party.

This development pursues the pleasure of exhibitionism and indicates the ways of living in postmodern times, that is to say, the dissolution of the limits of privacy. Each text expresses publicly what in the modern society was considered in bad taste: personal and trivial experiences without avoiding any subject.

Also the texts communicate fustigation impoliteness, on bilateral interactions, that is to say, interactions characterized by reciprocity in the impolite attitude as is shown 
by texts 1 and 5 , and on unilateral actions, that is to say, the impolite attitude appears as an individual manifestation, as shown by texts 2,3 and 4 .

By means of a language charged with violence, the first two texts exhibit fustigation impoliteness by refractoriness. In text (1), Moria Casan, in a face to face interaction, starts the conflict provocatively by censuring her daughter because Sofia loves women. Casan's refractoriness can be explained as follows: Moria represents a set of values of a certain antagonist group (the modern generation), therefore, she perceives in her daughter (the postmodern generation) affiliation to a group of persons having same sex relationships. On the part of Moria, there is a primary attack to the values of the group represented by Sofia, and, simultaneously, there is an implicit defense of the values of Moria's generational group, probably the biggest group in society. However, above all there is Moria's impulse towards extimacy and an imposed and unwanted extimacy on her daughter. With respect to emotions, Moria displays a high degree of intensity in her negative emotions and exhibits her innermost character without inhibition.

In addition, there is a general social rejection among network comments, expressing emotions such as anger and disgust, through sarcasm, as an offensive weapon to carry out fustigation impoliteness. In fact, commentators react with swearing words towards the inappropriate topic of conversation between mother and daughter, and the premeditated and imposed extimacy over Sofía.

In text (5), each one of the contenders, Ventura and Casella, develops his wish for increasing their own dominance over the other, to achieve higher ratings among their fans. Both contenders appeal directly to fustigation impoliteness by refractoriness and also, each one inflicts on the other an attributed and imposed extimacy, which presents an unwanted intrusion into each one's private life.

The radio fight ends on Twitter, and that introduces the negative comments of the fans. Those comments enable the researcher to reconfirm the retrospective view of the analyst (Kaul de Marlangeon, 2012).

Texts (2), (3) and (4) set out confessions performed by their protagonists with respect to matters affecting their privacy. In those texts, the speaker's extimacy and the extimacy imposed on the hearer or third parties concerned or attributed to them, involve all the protagonists.

Regarding the difference between the preceding texts (1) and (5), on one hand, and texts (2), (3) and (4), on the other, the speaker's extimacy is a self-face work to save his/her own face with the purpose of promoting their personal ego through publicizing his/her intimate relationships. The protagonists expose their problems with their fans in mind. It is quite clear that their comments are intended for exhibiting and promoting segments of their lives and thinking about themselves according to their fans' viewpoints. They realize that they have gained social prominence and a fairly high public profile.

Among commentators of Twitter, there is either an acceptance or a rejection of such expressions. This situation provides the analyst with a spontaneous consultation process to corroborate the nature of those behaviors, which are shocking for a part of society and funny for the other. 
In most cases, the commentators employ fustigation impoliteness imbued with negative emotions. As a result, certain celebrities involved end up being injured and others victimized, as one can see in network comments.

In the comments of text (2), Fabian Cubero presents himself as a victim, because many people exhibit positive emotions, such as sympathy or empathy towards him, while some other people show, at most, disgust when Cubero is called cuckold. Nicole Neumann, conversely, is criticized, scorned and insulted.

In the comments of text (3), Scioli takes the brunt of the damage and people insult him: conman, cynic, liar, abuser, coward. So far, he was a politician with Presidential ambitions but, at the present time, his hypocrisy was disclosed to the people who, therefore, do not forgive him for the abortion issue. In his former electoral campaign, Scioli had held an opposite opinion to legalizing abortion.

In text (4) commentators give a negative opinion about Barby Franco, whom they consider a gold digger.

What imposed and attributed extimacy have in common with social media comments is that both are criticisms aimed at discrediting the subject to which they refer. However, they differ in that social media comments make use of preconceived general notions among the audience and for that reason they are effective in achieving their goal. Conversely, imposed and attributed extimacy plant a new concept or communicate a new idea the public had not previously thought of by means of which they gain knowledge of the subject matter in question.

\section{CONCLUSIONS}

Nowadays, media exhibitionism for ego promotion has a broad spectrum of realization, especially when a big name turns on his/her extimacy or when some celebrity inflicts an imposed and/or attributed extimacy to his/her antagonist.

These two kinds of extimacy activity have different effects on the commentators, especially negative ones that confirm the trend that negative practices and negative emotions are being spread to society as a whole, mainly through fustigation impoliteness.

The dilution phenomenon of the difference between public and private lives is principally due to the fact that celebrities become more and more conscious of the importance attributed to them by network commentators, a new natural environment in the current society. This has transformed their actions, up to the smallest detail, into actions they perform for their fans.

(C) Silvia Kaul de Marlangeon, 2018

\section{REFERENCES}

Andrieş, A. M. (2011). Positive and Negative Emotions within the Organizational Context. Global Journal of Human Social Science, 11 (9) Version 1.0.

Arndt, H. y Janney, R. (1985). Politeness revisited: cross-modal supportive strategies. IRAL. XXIII (4), 281-300.

Bauman, Z. (2007). Vida de consumo. Buenos Aires: Fondo de Cultura Económica.

Bauman, Z. (2012). Esto no es un diario. Buenos Aires: Paidós.

Bravo, D. (1999). ¿Imagen 'positiva' vs. imagen 'negativa'? Pragmática socio-cultural y componentes de face. Oralia 2, 155-184. 
Bravo, D. (2009). Pragmática, sociopragmática y pragmática sociocultural del discurso de la cortesía. Una introducción. Bravo, D., Hernández Flores, N. y Cordisco, A. (Eds.), Aportes pragmáticos, sociopragmáticos y socioculturales a los estudios de la cortesía en español. (Vol. 2, pp. 31-68). Buenos Aires: Programa EDICE-Dunken.

Brown, P. y Levinson, S. C. ([1978] 1987) Politeness: Some universals in language usage. Cambridge: Cambridge University Press.

Coseriu, E, (1981) Lecciones de lingüistica general. Madrid: Gredos.

Chóliz, M. y Gómez, C. (2002). Emociones sociales: enamoramiento, celos, envidia y empatía. F. Palmero, E.G. Fernández-Abascal, F. Martínez y M. Chóliz (Eds.), Psicología de la Motivación y Emoción (pp. 395-418). Madrid: McGrawHill.

Fraser, B. (1994). Pragmatic Research: Methodological Issues. R.E. Asher y J.M.Y. Simpson (Eds.), The encyclopedia of language and linguistics. Multilingua, 18-4, 391-433.

Kaul de Marlangeon, S. (1995). La Fuerza de Cortesía - Descortesía y sus Estrategias en el Discurso Tanguero de la década del '20. RASAL. Año III No 3, 7-38. www.edice.org/Documentos/ SKaul.pdf.

Kaul de Marlangeon, S. (2005). Descortesía de fustigación por afiliación exacerbada o refractariedad (cap. 11). D. Bravo (Ed.), Estudios de la (des) cortesía en español. Categorías conceptuales y aplicaciones a corpora orales y escritos. (Vol. I, pp. 299-318). Buenos Aires: Programa EDICE-Dunken.

Kaul de Marlangeon, S. (2010). Perspectiva topológica de la descortesía verbal. Comparación entre algunas comunidades de práctica de descortesía del mundo hispanohablante. F. Orletti y L. Mariottini (Eds.), (Des)cortesía en español. Espacios teóricos y metodológicos para su estudio (pp. 71-86). Roma: Universidad Roma Tre - Programa EDICE.

Kaul de Marlangeon, S. and Alba-Juez, L. (2012a). A typology of verbal impoliteness behaviour for the English and Spanish Cultures. Revista Española de Lingüistica Aplicada (RESLA), $25,69-92$.

Kaul de Marlangeon, S. (2012b). Encuadre de aspectos teórico-metodológicos de la descortesía verbal en español. Escamilla Morales, J. y Vega, G.H. (Eds.), Miradas multidisciplinares a los fenómenos de cortesía y descortesía en el mundo hispánico (pp. 76-106). Barranquilla-Estocolmo: Universidad del Atlántico - Programa EDICE.

Kaul de Marlangeon, S. (2017) Tipos de descortesía verbal y emociones en contextos de cultura hispanohablante. SOPRAG (Pragmática Sociocultural. Revista Internacional sobre Lingüística del Español) DE GRUYTER, 5(1), 1-23.

Lipovetsky, G. (2002). La era del vacío. Barcelona: Anagrama.

Piqueras, et al. (2010). Emociones negativas y salud. Avances en psicología latinoamericana, (18)1, $33-57$.

Tisseron, S. (2002). L'intimité surexposée. Paris: Flammarion.

Tisseron, S. (2011). Intimité et extimité. Le Seuil Communications 88, 83-91.

\section{Article history:}

Received: 09 August 2017

Revised: 21 August 2017

Accepted: 28 August 2017

\section{For citation:}

Kaul de Marlangeon, Silvia (2018). Fustigation Impoliteness, Emotions and Extimacy in Argentine Media Celebrities. Russian Journal of Linguistics, 22 (1), 161-174. doi 10.22363/23129182-2018-22-1-161-174. 


\title{
Bionote:
}

SILVIA KAUL de MARLANGEON is a Doctor of Linguistics and a full professor at the National University of Río Cuarto, Argentina. Her current research focuses on the analysis of linguistic politeness and impoliteness from a discursive-socio-cultural point of view. Within this field, she has published numerous papers and she has lectured in several countries. In 1995 she provided her particular theoretical approach to (im)politeness. The pioneer character of this work was acknowledged by Research on Politeness in the Spanish-Speaking World, Laurence Erlbaum Associates (2007) and Pragmatics. Cognition, Context \& Culture, Mc Graw Hill (2016). Contact information: e-mail: SKaul@arnet.com.ar

DOI: 10.22363/2312-9182-2018-22-1-161-174

\section{НАРОЧИТАЯ НЕВЕЖЛИВОСТЬ, ЭМОЦИИ И ЭКСТИМНОСТЬ В РЕЧИ МЕДИЙНЫХ ЗНАМЕНИТОСТЕЙ АРГЕНТИНЫ}

\author{
Сильвия Каул де Марланьон \\ Национальный университет Рио Куарто \\ X5804BYA Río Cuarto, Córdoba, Аргентина
}

\begin{abstract}
Целью исследования явилось установление связи между нарочитой невежливостью (тип невежливости, вошедший в классифицию невежливых речевых актов в работах [Kaul de Marlangeon, 2005, 2008; Kaul de Marlangeon \& Alba-Juez, 2012a]), эмоциями и экстимностью на материале дискурса медийных знаменитостей аргентинского региона Рио-де-ла-Плата. Экстимость говорящего или слушающего рассматривается в статье как нарушение норм в условиях агрессивных взаимоотношений. Она используется говорящим для самопродвижения посредством СМИ, что увеличивает степень интимности с собеседником, демонстрируемой на публике. В рамках социокультурного подхода это исследование, с одной стороны, изучает нарочитую невежливость как характерную черту поведения медийных знаменитостей на публике, с другой, ставит задачу рассмотреть, какими типами экстимности оно обусловлено.
\end{abstract}

Ключевые слова: нарочитая невежливость; эмочии; медийная личность; экстимность говорящего; экстимность, обращенная на слушающего

\section{История статьи:}

Дата поступления в редакцию: 09 августа 2017

Дата принятия к печати: 8 августа октября 2017

\section{Для цитирования:}

Kaul de Marlangeon, Silvia (2018). Fustigation Impoliteness, Emotions and Extimacy in Argentine Media Celebrities. Russian Journal of Linguistics, 22 (1), 161-174. doi 10.22363/23129182-2018-22-1-161-174.

\section{Сведения об авторе:}

СИЛЬВИЯ КАУЛ ДЕ МАРЛАНЬОН - доктор, профессор Национального университета Рио Куарто, Аргентина. В настоящее время изучает выражение вежливости и невежливости в языке с дискурсивно-социокультурной точки зрения. По данной теме ею опубликовано значительное количество статей и прочитано большое количество лекций в разных странах. В 1995 году автор предложила свой теоретический подход к (не)вежливости. Оригинальность и новизна этого подхода отражены в статьях, которые вошли в тематические сборники Research on Politeness in the Spanish-Speaking World (Laurence Erlbaum Associates, 2007) и Pragmatics. Cognition, Context \& Culture (Mc Graw Hill, 2016). Контактная информаиия: e-mail: SKaul@arnet.com.ar 